\title{
Air Pollution and COVID-19: A Comparison of Europe and the United States
}

\author{
Peter John Fos ${ }^{1 *}$, Peggy Ann Honore ${ }^{2}$, Russel L Honore ${ }^{3}$
}

\author{
${ }^{1}$ Dillard University, USA \\ ${ }^{2}$ LSU Health Sciences Center School of Public Health School of Medicine, USA \\ ${ }^{3}$ Louisiana GreenARMY, USA \\ *Corresponding Author:pfos@dillard.edu
}

Citation: Fos, P. J., Honore, P. A. and Honore, R. L. (2021). Air Pollution and COVID-19: A Comparison of Europe and the United States. European Journal of Environment and Public Health, 5(2), em0074. https://doi.org/10.21601/ejeph/9706

\section{ARTICLE INFO}

Received: 2 Nov. 2020

Accepted: 2 Dec. 2020

\begin{abstract}
The objective of this study was to compare the cases of COVID-19 deaths and cases in the United States and Europe. The area selected in the United States was parishes (counties) in Louisiana along the Mississippi River which is globally known as "Cancer Alley." These parishes have been investigated in the past due to high levels of air pollution. The relationship of air pollution and COVID-19 was evaluated. Data from the Louisiana Department of Health was abstracted for the 11 parishes and infection, mortality, and case-fatality rates were calculated and compared to the remainder of the state. The racial distribution of deaths, and mortality and casefatality rates were determined in the 11 Cancer Alley parishes. Additionally, risk ratios of infection and mortality were determined. Results indicated that infection, mortality, and case-fatality rates were higher in the 11 Cancer Alley parishes where chronic exposure to air pollution has occurred. The COVID-19 cases and deaths were higher in the 11 Cancer Alley parishes when compared to the remainder of the state. When stratified by race, infection, mortality, and case-fatality rates were higher among Blacks in the 11 Cancer Alley parishes. The risk of infection and mortality was higher in the 11 Cancer Alley parishes, as well as among Blacks in these parishes. Our research adds to others that document the effects of air pollution on COVID-19, as well as the historical patterns of health disparities and environmental injustices in Cancer Alley. We offer a set of progressive policy recommendations as a pathway to actions for sustainable change, which can inform risk mitigating strategies worldwide.
\end{abstract}

Keywords: air pollution, COVID-19, health disparities

\section{INTRODUCTION}

When the novel coronavirus disease 2019 (COVID-19) first emerged in late 2019 in China, not very much was known about it or how it spread. Since then, a significant amount of research has been done focused on clinical characteristics of COVID-19 cases and the causes of deaths. The first research was conducted in Chinese hospitals. The novel aspects of COVID19 centered around this new form of SARS-corona virus with no known effective treatment or vaccine.

Initial finding from Chinese research identify clinical signs, as well as contributing co-morbidities. The most common clinical characteristic was fever and abnormal lung radiographs (Guan, Ni, Zhang, et al., 2020). Another study showed that age was a contributing factor to mortality. Younger cases usually survived and were discharged from the hospital, and a significant proportion of deaths were among those over the age of 60 years (Ruan, Yang, Wang, et a.1, 2020). One study found that the median time from identification as a positive COVID-19 case to death was less than 20 days, and those who were discharged were hospitalized 22 days. More importantly, this and other studies found that those who died had at least one chronic co-morbidity, with hypertension and diabetes being the most common (Zhou, Yu, Du, et al., 2020; Guan, Liang, Zhao, et al., 2020). Following this early research, focus was placed on co-morbidities including hypertension, diabetes, obesity, cardiovascular disease, obesity, and other chronic diseases (Yang, Zheng, Gou, et al., 2020).

As COVID-19 spread across the globe these earlier recognized co-morbidities were seen in cases and deaths. However, the effect of the environment was first seen in Northern Italy. Studies have shown that Northern Italy has exceeded regulatory limits of air pollution from at least the past decade. These same areas showed geographic differences in the COVID-19 outbreak in Italy, in both cases and deaths (Remuzzi and Remuzzi, 2020). The relationship between COVID-19 and air pollution that had been reported earlier in China, which alerted scientists and researchers in Italy and Europe (Zhu, Xie, Huang, and Cao, 2020). COVID-19 cases quickly increased, beginning in February 2020, with case- 
fatality rates in Italy increasing with age (Onder, Rezza, and Brusaferro, 2020).

Early in the COVID-19 pandemic, an outbreak in Lombardy drew attention. It has been known for the highest levels of high fine particulate matter $\left(\mathrm{PM}_{2.5}\right)$ and nitrogen dioxide $\left(\mathrm{NO}_{2}\right)$ occurred in Northern Italy, especially Lombardy (EEA, 2019). It was postulated that the coronavirus was present in Lombardy long before the new cases, and the outbreak, were recognized (Cereda, Tirani, Rovida, et al., 2020). This was confirmed as the emergence of new cases continued after the governmental lockdown. The above information resulted in Italian researchers suggesting a relationship between COVID19 and air pollution existed. Further studies evaluated longterm levels of air pollutants in the areas with the highest number of COVID-19 cases and deaths. It was suggested that the presence of COVID-19, known comorbidities, and longterm levels of air pollution were correlates of the outbreak (Corticini, Frediani, and Caro, 2020). Others have suggested that risk of COVID-19 infection, and the resulting pandemic in Italy, is associated with chronic high level of air pollution (Fattorini and Regoli, 2020).

Similar effects of air pollution on the COVID-19 pandemic were seen in France. In a study of three French cities (Paris, Marseilles, and Lyon) advanced computer science techniques were used to investigate the association between COVID-19 and air pollution. A result of the study showed that $\mathrm{PM}_{2.5}$ levels were associated with COVID-19 deaths. The study also found cut-off levels of $\mathrm{PM}_{2.5}$ levels at which air pollution is linked to COVID-19. If pollution levels are reduced below the identified cut-offs, it is expected that COVID-19 deaths would decrease (Magazzino, Mele, and Schneider, 2020).

Given the findings in Italy and France, studies were conducted in the Netherlands. In one study the link between air pollution and COVID-19 was estimated in 355 municipalities. The results of this study included a positive relationship between air pollution levels and COVID-19 cases, hospitalizations, and deaths. Hot spots of COVID-19 cases and deaths occurred in cities with high levels of $\mathrm{PM}_{2.5}$. Levels of $\mathrm{PM}_{2.5}$ have exceeded governmental regulations for many years. Similar correlations were found with $\mathrm{NO}_{2}$. Additionally, cases and deaths in rural areas were related to air pollution from agricultural farming (Cole, Ozgen, and Strobi, 2020).

The findings in Italy and other areas in Europe should not come as a surprise. During the SARS epidemic in 2002, 349 deaths and 5,327 cases were seen in China. The spread of SARS varied across the country and was affected by air quality. Research revealed that there was a positive association between air pollution and SARS mortality (Cui, Zhang, Froines, 2003). The recent emergence of viral outbreaks and epidemics has been shown to be related to socioeconomic, environmental, and ecological factors. The environmental factor that may have the most influence is air pollution (Jones, Patel, Levy, et al., 2008. The relationship between air pollution and respiratory viral infection has been studied for many years. This relationship has been shown to increase the risk of hospitalization and mortality (Ciencewicki and Jaspers, 2007).

Air pollution has been identified as a contributing factor to many diseases and conditions, which have been found to be comorbidities for COVID-19 cases and deaths. Long-term exposure to air pollution increases type 2 diabetes (T2D) risk, which is a common chronic disease in the US and across the world (Tessum, Apte, Goodkind, et al., 2019). Long-term exposure to $\mathrm{PM}_{2.5}$ matter and $\mathrm{NO}_{2}$ levels are significantly associated with elevated T2D prevalence (Wang, Xu, Zing, et al., 2014). Air pollution has been associated with acute respiratory syndrome and influenza-like illnesses (Gouda, Shaikh, and Bhandary, 2018; Huang, Zhow, Chen, et al., 2016). Recent studies have informed the impact of air pollution and adverse health conditions, including syncytical virus in children, measles, and other health conditions (Brunekreef and Holgate, 2002; Peng, Zhan, Tao, et al., 2020; Ye, Fu, Mao, and Shang, 2016).

Chronic exposure to air pollution has been linked to health problems for several years (Kampa and Castanas, 2008). Air pollution is the major environmental risk factor for cardiovascular disease (Landrigan, Fuller, Fisher, et al., 2018). The Global Burden of Disease (GBD) study states that approximately 9 million deaths can be directly attributable to environmental air pollution annually (Cohen, Brauer, Burnett, et al., 2015). $\mathrm{PM}_{2.5}$ has a disproportionate effect on countries poor air quality and causes 4.2 million deaths per year (Fuller, Rahona, Fisher, 2018). Additionally, nonchemical environment factors, including temperature, noise exposure, socioeconomic factors, occupational risks, and built environments, have been shown to intensify the association of air pollution and cardiovascular disease (Rajagopalan, AlKindi, and Brook, 2018).

Hypertension has been correlated with $\mathrm{PM}_{2.5}$ exposure. In a large-scale meta-analysis blood pressure was found to be positively correlated with $\mathrm{PM}_{2.5}$ exposure. Long-term exposure resulted in the strongest correlation (Liang, Zhang, Zhao, 2018). A study of outdoor biomass air pollution found an association between total suspended particles (TSP) and hospital admission from hypertension. Increases in TSP concentrations, especially during times of harvest, increase hypertension-related hospital admissions (Arbex, Saldiva, Pereia, and Braga, 2010). In a nationwide study in China, a positive association was found between air pollution and hypertension. Long-term exposure to $\mathrm{PM}_{2.5}$ air pollution were associated with the prevalence of hypertension, especially in middle-aged, obese, and urban study participants (Liu, Chen, Zhao, et al., 2018). In the study of the global association between air pollution and hypertension a significant association was found. Significant associations were found between long-term exposures to $\mathrm{PM}_{2.5}$ with hypertension, with stronger associations among men, Asians, North Americans, and areas of the world with relatively higher levels of air pollution (Yang, Qian, Howard, et al., 2018).

To compare Europe and the United States an area of relative higher levels of air pollution along the Mississippi River in Louisiana was selected. This area has been colloquially called a petrochemical corridor, with over 150 petrochemical facilities, the highest concentration of such facilities in the Western Hemisphere. This area has high incidence and prevalence rates of some cancers and has been called Cancer Alley (Shamlian, 2019). Cancer Alley is an 85-mile stretch along the Mississippi River between New Orleans and Baton Rouge. This area consists of predominantly low income, Black residents who live immediately adjacent to the facilities and 
Table 1. COVID-19 Infection, Mortality, Case-Fatality Rates, and Risk Ratios

\begin{tabular}{|c|c|c|c|c|c|}
\hline Area & Infection Rate\& & Mortality Rate* & Case-Fatality Rate $^{\wedge}$ & Infection Risk+ & Mortality Risk\# \\
\hline 11 Mississippi River Parishes & $1,654.23$ & 100.39 & 6.01 & 1.71 & 2.62 \\
\hline 53 Louisiana Parishes & 968.36 & 38.26 & 5.01 & & \\
\hline Ascension & 905.18 & 60.96 & 5.06 & 0.93 & 1.59 \\
\hline East Baton Rouge & $1,127.80$ & 58.00 & 5.40 & 1.16 & 1.52 \\
\hline Iberville & $2,150.04$ & 113.08 & 6.15 & 2.22 & 2.96 \\
\hline Jefferson & $2,160.03$ & 118.50 & 5.49 & 2.23 & 3.10 \\
\hline Orleans & $1,989.01$ & 133.32 & 6.84 & 2.05 & 3.48 \\
\hline Plaquemines & $1,107.90$ & 110.02 & 10.12 & 1.14 & 2.88 \\
\hline St. Bernard & $1,284.82$ & 47.09 & 3.79 & 1.33 & 1.23 \\
\hline St. Charles & $1,386.06$ & 95.95 & 6.66 & 1.43 & 2.51 \\
\hline St. James & $1,654.34$ & 113.92 & 8.02 & 1.71 & 2.98 \\
\hline St. John the Baptist & $2,222.38$ & 215.23 & 9.03 & 2.30 & 5.63 \\
\hline West Baton Rouge & 937.09 & 108.36 & 12.10 & 0.97 & 2.83 \\
\hline
\end{tabular}

Sources: Louisiana Department of Health - Data as of June 29, 2020

U.S. Census Bureau

\&crude rate

*race-adjusted, per 100,000 population

^ percent

+Infection/Mortality risk = infection rate (mortality rate) in 11 Mississippi River parishes/infection rate (mortality rate) in the remaining 53 parishes

\#Infection/Mortality risk = infection rate (mortality rate) in the parish/infection rate (mortality rate) in the remaining 53 parishes

are referred to as "fenceline" communities. (U.S. Census Bureau, 2020). However, it is important to note that one Cancer Alley parish, Ascension, does show a different socioeconomic demographic. Because of petrochemical expansion and employment opportunities at the petrochemical facilities, Ascension parish havs the highest median household income in LA and $72.6 \%$ of the residents are $72.6 \%$ white (U.S. Census Bureau, 2020). However, Blacks still live closest to the facilities in fenceline communities across Ascension. A study of the impact of emissions from petrochemical facilities on lung cancer rates found associations with long-term exposures. However, the study could not establish statistical significance in dose-response analysis (Simonsen, Scribner, Su, et al., 2010). A second study evaluating spatial variation in breast cancer mortality did find a meaningful difference across parishes of Louisiana. This study found that there were shorter survival times for women who lived in parishes along Cancer Alley, and attributed this finding to several factors including chemical emissions from petrochemical facilities (Carroll, Lawson, Jackson, and Zhao, 2017).

The debate over whether lung cancer rates are statistically significantly higher along Cancer Alley due to petrochemical emissions, has now taken on a new perspective, COVID-19 deaths. The infection rates and mortality rates of COVID-19 are much higher in the parishes in Cancer Alley than other areas in Louisiana. In fact, for some time the COVID-19 mortality rate in St. John the Baptist Parish was the highest in the U.S. (CNN, 2020). The study reported in this paper will investigate the magnitude of the impact of air pollution on COVID-19 cases and deaths in the parishes along the Mississippi River.

A recent study found that elevated $\mathrm{PM}_{2.5}$ levels are associated with increased COVID-19 deaths, after controlling for socioeconomic factors and comorbidities ( $\mathrm{Xu}$, Nethery, Sabath, et al., 2020). One of this study's finding was that Blacks were more likely to live in areas with high $\mathrm{PM}_{2.5}$ levels. The study showed that areas with higher percentages of Blacks had higher COVID-19 deaths rates, which was confirmed by a previous study that evaluated the relationship between diabetes and COVID-19 deaths (Fos, Honoré, and Kellum, 2020).

\section{METHODS}

Data from the Louisiana Department of Health was analyzed from Ascension, East Baton Rouge, Iberville, Jefferson, Orleans, Plaquemines, St. Bernard, St. Charles, St. James, St. John the Baptist, and West Baton Rouge parishes. The COVID-19 infection rate and mortality rate were calculated and compared to the other 53 parishes in Louisiana. Additionally, the case-fatality rate was calculated for comparison purposes, as well as analysis of the relationship between Black/White population and Black/White COVID-19 mortality rate ratios. The case-fatality rates for Blacks and Whites were compared. Population data were obtained from the U.S. Census, 2019 estimates (U.S. Census Bureau, 2020).

\section{RESULTS}

Table 1 presents COVID-19 infection, mortality, and casefatality rates for Louisiana and the 11 study parishes. Other than Ascension and West Baton Rouge parishes, the infection rate was higher in parishes along Cancer Alley than the rate for the other 53 parishes in the state. The infection rate for the 11 study parishes was $1,654.23$ cases per 100,000 population, compared to 968.36 cases per 100,000 for the remainder of the state. Evaluating parishes individually, the highest infection rate was seen in St. John the Baptist $(2,222.38$ cases per 100,000 population), followed by Jefferson, Iberville, and Orleans parishes $(2,160.03,2,150.04,1,989.01$ cases per $100,000)$. The infection rate in St. John the Baptist Parish was 2.30 times greater than the infection rate for the remaining 53 
Table 2. COVID-19 Mortality, Case-Fatality Rates, by Race

\begin{tabular}{ccccc}
\hline Area & $\begin{array}{c}\text { Mortality Rate, } \\
\text { Blacks* }\end{array}$ & $\begin{array}{c}\text { Mortality Rate, } \\
\text { Whites* }\end{array}$ & $\begin{array}{c}\text { Black Mortality } \\
\text { Risk+ }\end{array}$ & Population Ratio^ $^{\wedge}$ \\
\hline 11 Mississippi River Parishes & 159.90 & 69.31 & 2.31 & 0.83 \\
\hline Ascension Parish & & & 3.52 & 0.43 \\
\hline East Baton Rouge & 88.84 & 25.23 & 1.42 & 0.98 \\
\hline Iberville & 71.95 & 50.72 & 2.53 & 0.99 \\
\hline Jefferson & 187.90 & 74.21 & 2.36 & 0.43 \\
\hline Orleans & 190.75 & 80.76 & & \\
\hline Plaquemines & 225.57 & 85.14 & & \\
\hline St. Bernard & & & & \\
\hline St. Charles & & & 2.65 & \\
\hline St. James & 156.89 & 64.12 & & \\
\hline St. John the Baptist & 203.11 & 67.33 & 3.02 & 0.37 \\
\hline West Baton Rouge & 184.27 & 231.40 & 0.80 & 0.99 \\
\hline
\end{tabular}

Sources: Louisiana Department of Health - Data as of June 29, 2020

U.S. Census Bureau

*per 100,000 population

+Black mortality risk = mortality rate among Blacks/mortality rate among Whites

${ }^{\wedge}$ Population ratio $=$ Black population/White population

parishes. The risk of infection in the 11 parishes is 1.71 times greater than in the remaining 53 parishes.

The race-adjusted mortality rate for the 11 Cancer Alley parishes was 100.39 deaths per 100,000 , which is more than two and a half times higher than for the remaining 53 parishes. Mortality rates are greater than the state's in all 11 parishes. St. John the Baptist Parish had the highest mortality rate (200.76 deaths per 100,000), followed by Orleans, Jefferson, St. James, and Iberville (133.33, 118.50, 113.92, and 113.08 deaths per 100,000, respectively). The risk of death in St. John the Baptist Parish is more than 5 and a half times greater than the other parishes in the state, and nearly twice greater than in Iberville, St. James, and Orleans parishes.

Case-fatality rates, the number of cases of COVID-19 who die, were greater in the 11 Mississippi parishes, $6.01 \%$ compared to $5.01 \%$ for the 53 remaining parishes. The casefatality rate was higher in all 11 parishes, except for St. Bernard Parish. The highest case-fatality rate is in West Baton Rouge Parish, 12.10\%, more than twice that for the remainder of the state. Plaquemines, St. John the Baptist, St. James, and Orleans parishes had high case-fatality rates of $10.12 \%, 9.03 \%, 8.02 \%$, 6.84 percent.

Table 2 shows mortality rates, mortality risk ratios, and population ratios by race. The Louisiana Department of Health does not report cases of COVID-19 infection by race, so infection rates by race could not be determined. Additionally, the Louisiana Department of Health does not report the racial distribution of deaths in parishes with less than 25 deaths. Given this, race-adjustment of mortality rates and racial distribution of deaths in Plaquemines and St. Bernard parishes was not available.

The mortality rate among Blacks in the 9 Cancer Alley parishes with available data was 159.90 deaths per 100,000, compared to 69.31 deaths per 100,000 among Whites. The highest mortality rate was in Orleans Parish, a rate of 225.57 deaths per 100,000 . Other high mortality death rates among Blacks were in St. James, West Baton Rouge, Iberville, Jefferson, St. John the Baptist, and St. Charles parishes. The highest mortality rate among Whites was in St. John the
Baptist Parish, 231.40 per 100,000 population. The lowest mortality rate among Blacks and Whites was in East Baton Rouge and Ascension Parishes, respectively (71.95 and 25.23 deaths per 100,000).

The risk of mortality among Blacks, compared to Whites, was 2.31 times higher in the 9 Cancer Alley parishes. This difference was seen in all 9 parishes, except for St. John the Baptist, where risk was higher among Whites. The mortality rate among Whites is greater than among Blacks in St. John the Baptist, which is probably due to the large number of nursing home deaths. Individually, the risk of mortality among Blacks in Ascension Parish was 3.52 higher than among Whites. The risk of mortality among Blacks in St. James and West Baton Rouge parishes was three times higher than among Whites. Parishes with a risk greater than two times higher included Iberville, Jefferson, Orleans, St. Charles, and West Baton Rouge.

It is interesting to evaluate the population distribution in the 11 Cancer Alley parishes. The total population of the 11 parishes is $1,635,750$, or $35.2 \%$ of the state. However, the 11 Cancer Alley parishes have nearly 50\% of all COVID-19 cases. Over $50 \%$ of COVID-19 deaths have occurred in the Cancer Alley parishes. The population of the 11 Cancer Alley parishes range from a low of 21,096 in St. James Parish, to a high of 440,059 in East Baton Rouge Parish. The racial distribution in the 11 Cancer Alley parishes is $55.5 \%$ Whites and $42.5 \%$ Blacks. The number of Whites range from 283,556 in Jefferson to 10,397 in St. James. Blacks range from 235,298 in Orleans to 4,941 in Plaquemines. The population of Whites is larger in the Cancer Alley parishes, except for Orleans and St. John the Baptist. Mortality rates among Blacks were higher in all Cancer Alley parishes, except for St. John the Baptist Parish. If COVID19 deaths were randomly distributed it is reasonable to expect that the mortality rates would be higher among Whites in all parishes. 


\section{DISCUSSION}

Our research found alarming rates of COVID-19 infection, mortality, and case fatality across the 11 Cancer Alley parishes of Louisiana. The rates in most of the study parishes are dramatically higher than the other 53 parishes in the state of Louisiana, and in all parishes the rates were higher than across the United States. The differences in mortality are more remarkable when evaluated across race. Blacks had, overall, two times higher mortality rates than their fellow parish White residents. These findings mimic those observed in Northern Italy, France, and the Netherlands.

The relationship of air pollution to COVID-19 infection and death is equally as troubling as the persistent suggested links to cancer. However, COVID-19 analysis is unmasking the disparities and harm from air pollution in confirmable outcomes close to the advent of the virus. Thom Davies in his research focused on Cancer Alley described such long-term exposure to air pollution as a pervasive form of "slow violence" where terror is manifested beyond just a singular event (Davies, 2019). Cancer research for associations in Cancer Alley are hindered plausibly because of the slow progression of the disease and a result of alliances between petrochemical corporations and policymakers to maintain existing structures. Louisiana historically ranks within the top tier of states in oil production and reserves. However, it is basically an economically poor state. The population is unhealthy and suffers from many of the comorbidities linked to infection of COVID-19. Over the past 30 years, Louisiana's health status when compared to other states has fluctuated very little as demonstrated by its $50^{\text {th }}$ ranking in 1990 and $49^{\text {th }}$ in 2019 (Terrell and James, 2020; United Health Foundation, 2019).

Pathways to eliminating harmful environmental injustices beckons for a confluence of progressive actions across all of determinants of health - Corporate, Political, and Social. The Corporate determinants can be a means to promote improvement in the social determinants by paying a living wage, providing access to healthcare and being good stewards of the environment. Conversely, corporate determinants, as seen in Cancer Alley, are often grounded in unchecked power by lacking transparency, establishing harsh environmental conditions where people live, and restricting knowledge needed for improving health (McKee and Stuckler, 2018).

Activism without policies to solidify change lacks sustainability (Terrell and James, 2020). In his book, the Political Determinants of Health, Daniel Dawes reveals that policies in fact bear a likeness to our values at a specific point in time. These Political Determinants of Health, in part, have a role to play in removing systemic obstacles that inhibit the creation of good health and health equity (Dawes, 2020). Policies to expand healthcare coverage, restrictions and monitoring of environmental hazards, or regulating punitive actions on environmental violators are examples of policies that promote good health and equity. Dawes also states that definitions of health equity boldly asserts that there should be no avoidable differences in health within a population. Subsequently, the existence of health inequities signifies that there actually is something that can be acted upon to remove those difference.
From an environmental justice perspective, pollution disparity warrants corrective action; inaction is in essence an injustice (Dawes, 2020). The $\mathrm{PM}_{2.5}$ exposure levels in Cancer Alley is a risk factor modifiable only by the corporate and political leaders who advance and authorize its continuance. Placing blame on the residents by asking them to modify human behaviors linked to commodities such as obesity, diabetes, or hypertension is not going to fully address the COVID-19 risks. Culpability rests, as well, with the structural systems that created the injustice.

Health policies are needed to bolster and sustain a plan of action in the United States, which can be used to inform risk mitigating strategies worldwide. These policy recommendations include:

- Establishment of an Environmental Health Trust Fund subsidized through mandated fees on all petrochemical facilities and oil refineries. Trust Fund use could be to increase research, create more healthcare structures for increased delivery of medical services and public health interventions, and build more platforms for outreach and advocacy training for residents.

- Mandate establishment of real-time online and roadside electronic systems for air monitoring and reporting by residents

- Expand mandates to include monitoring for chemical compounds

\section{CONCLUSIONS}

The effects of chronic air pollution on the COVID-19 pandemic are similar in China, Europe and the United States. These effects in the United States are due to inaction on environmental and structural injustices and health inequities in Louisiana. This means another 30 years of ranking $49^{\text {th }}$ or $50^{\text {th }}$ in health status and continued excessive rates of premature death in the United States. In Louisiana, as well as in Europe, the next pandemic is likely to have similar impacts on the population as what is currently being experienced. Action is needed now and findings from this research, and others, are intended to inform a movement towards reforms in policy, citizen activism, and creating systems for equity and justice.

\section{REFERENCES}

Arbex, M. A., Saldiva, P. H. N., Pereira, L. A. A. and Braga, A. L. F. (2010). Impact of outdoor biomass air pollution on hypertension hospital admissions. Journal of Epidemiology and Community Health, 64, 573-579. https://doi.org/ 10.1136/jech.2009.094342

Brunekreef, B. and Holgate, S.T. (2002). Air pollution and health. The Lancet, 360(9341), 1233-1242. https://doi.org/ 10.1016/s0140-673(02)11274-8 
Carroll, R., Lawson, A.B., Jackson, C.L. and Zhao, S. (2017). Assessment of spatial variation in breast cancer-specific mortality using Louisiana SEER data. Social Science \& Medicine, 193, 1-7. https://doi.org/10.1016/j.socscimed. 2017.09.045

Cereda, D., Tirani, M., Rovida, F., et al. (2020). The early phase of the COVID-19 outbreak in Lombardy, Italy. Arxiv preprint. https://arvix.org/ftp/arvix/papers/2003/2003.09320. pdf

Ciencewicki, J. and Jaspers, I. (2007). Air pollution and respiratory viral infection. Inhalation Toxicology, 19, 11351146. https://doi.org/10.1080/08958370701665434

CNN. Tiny Louisiana parish has the highest COVID-19 death rate in US (2020). https://www.cnn.com/videos/us/2020/ 04/16/coronavirus-COVID-19-louisiana-st-john-deathlavandera-pkg-nr-vpx.cnn

Cohen, A. J., Brauer, M., Burnett, R., et al. (2017). Estimates and 25-year trends of the global burden of disease attributable to ambient air pollution: An analysis of data from the Global Burden of Diseases Study 2015. The Lancet, 389, 1907-1918. https://doi.org/10.1016/S0140-6736(17) 30505-6

Cole, M. A., Ozgen, C. and Strobi, E. (2020). Air pollution exposure and COVID-19 in Dutch municipalities. Environmental and Resource Economics, 76, 581-610. https://doi.org/10.1007/s10640-020-00491-4

Corticini, E., Fredani, B. and Caro, D. (2020). Can atmospheric pollution be considered a co-factor in extremely high levels of SARS-CoV-2 lethality in Northern Italy? Environmental Pollution, 114465. https://doi.org/10.1016/j.envpol.2020. 114465

Cui, Y., Zhang, Z., Froines, J., et al. (2003). Air pollution and case fatality of SARS in the People's Republic of China: an ecologic study. Environmental Health, 2, 15. http://www.ehjournal.net/content/2/1/15

Davies, T. (2019). Slow violence and toxic geographies: Out of Sight to whom? EPC Politics and Space. https://doi.org/10.1177/2399654419841063

Dawes, D. (2020). The Political Determinants of Health. Baltimore, MD: Johns Hopkins University Press.

EEA, European Environmental Agency (2020). Monitoring COVID-19 impacts on Air Pollution. Dashboard Prod-ID: DAS-217-en. https://eea.europa.eu/themes/air/airquality-and-COVID19/monitoring-COVID19-impacts-on

Fattorini, D. and Regoli, F. (2020). Role of chronic air pollution levels in COVID-19 outbreak risk in Italy. Environmental Pollution, 264, 114732. https://doi.org/10.1016/j.envpol. 2020.114732

Fos, P. J., Honoré, P. A. and Kellum, K. P. (2020). The relationship of diabetes and COVID-19: A health disparity. Diabetes Complications, 4(1), 1-8.

Fuller, R., Rahona, E., Fisher, S., et al. (2018). Pollution and non-communicable disease: Time to end the neglect. Lancet Planet Health, 2, e96-e98. https://doi.org/10.1016/ S2542-5916(18)30020-2
Gouda, M. M., Shaikh, S. B. and Bhandary, V. P. (2018). Inflammatory and fibrinolytic system in acute respiratory disease syndrome. Lung, 196(5), 609-616. https://doi.org/10.1007/s00408-018-0150-6

Guan, W., Ni. Z., Liang, C., et al. (2020). Clinical characteristics of coronavirus disease 2019 in China. New England Journal of Medicine, 382, 1708-1720. https://doi.org/10.1056/ NEJMoa2002032

Guan, W., Liang, W., Zhao, Y., et al. (2020) Comorbidity and its impact on 1590 patients with COVID-19 in China: A nationwide analysis. European Respiratory Journal, 55, 2000547. https://doi.org/10.1183/13993003.00547-2020

Huang, L., Zhou, L., Chen, J., Chen, K., Liu, Y., Chen, X. and Tang, F. (2016). Acute effects of air pollution on influenzalike illness in Nanjing, China: a population-based study. Chemosphere, 147, 180-187. https://doi.org/10.1016/ j.chemosphere.2015.12.082

Jones, K. E., Patel, N. C., Levy, M. A., et al. (2008). Global trends in emerging infectious diseases. Nature, 451(7181), 990993. https://doi.org/10.1038/nature06536

Kampa, M. and Castanas, E. (2008). Human health effects of air pollution. Environmental Pollution, 151(2), 362-367. https://doi.org/10.1016/j.envpol.2007.06.012

Landrigan, P. J., Fuller, R., Fisher, S., et al. (2008). The Lancet Commission on pollution and health. The Lancet, 391, 462512. https://www.thelancet.com/commission/pollutionand-health

Liang, R., Zhang, B., Zhao, X., Ruan, Y., Lian, H. and Fan, Z. (2014). Effect of exposure to $\mathrm{PM}_{2.5}$ on blood pressure: a systematic review and meta-analysis. Journal of Hypertension, 32(11), 2130-2141. https://doi.org/1097/ HJH.0000000000000342

Liu, C., Chen, R., Zhao, Y., et al. (2017). Associations between ambient fine particulate air pollution and hypertension: A nationwide cross-sectional study in China. Science of the Total Environment, 584, 869-874. https://doi.org/10.1016/ j.scitotenv.2017.01.133

Magazzino, C., Mele, M. and Schneider, N. (2020). The relationship between air pollution and COVID-19 related deaths: An application to three French cities. Applied Energy, 279, 115835. https://doi.org/10.1016/j.apenergy. 2020.115835

McKee, M. and Stuckler, D. (2018). Revisiting the corporate and commercial determinants of health. American Journal of Public Health, 108(9), 1167-1170. https://doi.org/10.2105 /AJPH.2018.304510

Onder, G., Rezza, G. and Brusaferro, S. (2020). Case fatality rate and characteristics of patients dying in relation to COVID-19 in Italy. Journal of the American Medical Association, 23(18), 1775-1776. https://doi.org/10.1001/ jama.2020.4683

Peng, L., Zhan, X., Tao, Y., Mi, S., Huang, J. and Zhang, Q. (2020). The effects of air pollution and meteorological factors on measles cases in Lanzhou, China. Environmental Science and Pollution Research, 27, 13524-13533. https://doi.org/10.1007/s11356-020-07903-4 
Rajagopalan, S., Al-Kindi, S. G. and Brook, R. D. (2018). Air pollution and cardiovascular disease. Journal of the American College of Cardiology, 72(17), 2054-2070. https://doi.org/10.106/j.jacc.2018.07.099

Remuzzi, A. and Remuzzi, G. (2020). COVID-19 and Italy: what next? The Lancet, 395(102321), 1225-1228. https://www.doi.org/10.1007/s11356-020-07903-4

Ruan, Q., Yang, K., Wang, W., et al. (2020). Clinical predictors of mortality due to COVID-19 based on analysis of data of 150 patients from Wuhan, China. Intensive Care Medicine, 6, 846-848. https://ddoi.org/10.1007/s00134-020-05991-x

Shamlian, J. (2019). High cancer risk plaques a Louisiana town near chemical plants. CBS News. July 24, 2019. Available at: https://www.cbsnews.com/news/cancer-alley-reservelouisiana-denka-plant-health-risk-higher-nationalaverage-2019-07-24/ (Accessed: 15 June 2020).

Simonsen, N., Scribner, R., Su, L.J., et al. (2010). Environmental exposure to emissions from petrochemical sites and lung cancer: The lower Mississippi Interagency Cancer Study. Journal of Environmental Public Health, 2010, 759645. https://doi.org/10.1155/2010/759645

Terrell, K. and James W. (2020). Air pollution and COVID-19: A double whammy for Black and impoverished communities in Cancer Alley. Tulane University Environmental Law Clinic. Available at: https://law.tulane.edu/sites/law.tulane.edu/ files/Files/Terrell\%20-\%20COVID-19\%20-\%20PM\%202.5 \%20Louisiana\%202020-5-14\%20WEB\%20VERSION.pdf

Tessum, C. W., Apte, J. S., Goodkind, A. L., et al. (2019). Inequity in consumption of goods and services adds to racial-ethnic disparities in air pollution exposure. Proceedings of the National Academy of Sciences, 116(13), 6001-6006. https://www.pnas.org/cgi/doi/10.1073/pnas. 1818859116

United Health Foundation. America's Health Rankings Annual Report 2019. Available at: https://www.americashealth rankings.org/learn/reports/2019-annual-report (Accessed: 1 June 2020).

U.S. Census Bureau. Quick Facts for Median Household Income. Available at: https:/www.census.gov/quickfacts/fact/table /plaqueminesparishlouisiana/PST045219 (Accessed: 1 June 2020).
U.S. Census Bureau. Quickfacts. Available at: https://www.census.gov/quickfacts/fact/table/US/PST0452 19 (Accessed: 15 June 2020).

Wang, B., Xu, D., Jing, Z., et al. (2014). Effect of long-term exposure to air pollution on type 2 diabetes mellitus risk: A systemic review and meta-analysis of cohort studies. European Journal of Endocrinology, 171, R173-R182. https://doi.org/10.1530/EJE-14-0365

Xu, X., Nethery, R. C., Sabath, M. B., Braun, D. and Dominici, F. (2020). Exposure to air pollution and COVID-19 mortality in the United States: A nationwide crosssectional study. medRxiv. https://doi.org/10.1101/2020.04. 05.20054502

Yang, B., Qian, Z., Howard, S. W., et al. (2018). Global association between ambient air pollution and blood pressure: A systematic review and meta-analysis. Environmental Pollution, 235, 576-588. https://doi.org/10.1016/j.envpol.2018.01.001

Yang, J., Zheng, Y., Gou, X., et al. (2020). Prevalence of comorbidities in eh novel Wuhan coronavirus (COVID-19) infection: A systematic review and meta-analysis. International Journal of Infectious Diseases, 94, 91-95. https://doi.org/10.1016/j.ijid.2020.03.017

Ye, Q., Fu, J., Mao, J. and Shang, S. (2016). Haze is a risk factor contributing to the rapid spread of respiratory syncytial virus in children. Environmental Science and Pollution Research, 23(20), 20178-20185. https://doi.org/10.1007/ s11356-016-7228-6

Zhou, F., Yu, T., Du, R., et al. (2020). Clinical course and risk factors for mortality of adult inpatients with COVID-19 in Wuhan China. The Lancet, 365, 1054-1065. https://doi.org/10.1016/S0140-6736(20)30566-3

Zhu, Y., Xie, J., Huang, F. and Cao, L. (2020). Association between short-term exposure to air pollution and COVID19 infection: evidence from China. Science of the Total Environment, 727, 138704. https://doi.org/10.1016/ j.scitotenv.2020.138704 